\section{A ditadura de 1964 e o governo da natureza: a construção de uma Amazônia geopolítica*}

\author{
The 1964 Brazilian coup d'état and \\ Geopolitics of the Amazon: making up \\ policies.
}

\section{Resumo}

O objetivo deste artigo é refletir sobre a constituição do território amazônico nas narrativas político-militares. Para sistematizar as narrativas que dão sentido às práticas territoriais no período militar, desde o golpe de 1964, este artigo propõe analisar as doutrinas geopolíticas de três generais e de um político, que ajudaram a compor um modus operandi para a Amazônia, a saber: Mário Travassos; Golbery do Couto e Silva; Meira Mattos; e Arthur Cezar Ferreira Reis. É nesse contexto discursivo que se aplica a doutrina da segurança nacional à Amazônia. Para ter um quadro mais amplo de práticas territoriais institucionalizadas por narrativas político-militares, este artigo propõe analisar a denominada escola geopolítica brasileira (MIYAMOTO, 1981) e suas reverberações para a geopolítica amazônica.

Palavras-chave: Geopolítica. Amazônia. Golpe de 1964. Travassos. Golbery. Meira Mattos. Ferreira Reis.

\begin{abstract}
TThe aim of this paper is to think on geopolitical narratives for the Brazilian Amazonia. To frame the narratives that give signification to territorial practices during the military period (1964 to 1985), this article targets to analyze the geopolitical doctrines of three generals and a politician who helped setting up a modus operandi for Amazonia, namely: Mario Travassos; Golbery do Couto e Silva; Meira Mattos; and Arthur Cezar Ferreira Reis. Those political and military narratives build up territorial practices. In this way, the article aims to analyze the so-called Brazilian geopolitical school (MIYAMOTO, 1981) and its echoes to establish institutional actions to the Brazilian Amazonia.
\end{abstract}

Keywords: Geopolitics. Amazonia. Travassos. Golbery. Meira Mattos. Ferreira Reis. 


\section{Introdução}

Por meio deste artigo, busca-se refletir acerca da constituição do território amazônico nas narrativas político-militares. Para sistematizar as narrativas que dão sentido às práticas territoriais no período militar, desde o golpe de 1964, este artigo propõe analisar as doutrinas geopolíticas de três generais e de um político, que ajudaram a compor um modus operandi para a Amazônia, a saber: Mário Travassos; Golbery do Couto e Silva; Meira Mattos; e Arthur Cezar Ferreira Reis. Nesse contexto doutrinário aplica-se a doutrina da segurança nacional à Amazônia dentro de uma geopolítica militar brasileira. Para ter um quadro mais amplo de práticas territoriais institucionalizadas por narrativas político-militares, este artigo propõe analisar a denominada escola geopolítica brasileira (Miyamoto, 1981) e suas reverberações para a geopolítica amazônica. ${ }^{2}$

No contexto do pensamento estratégico, inicialmente, emerge tentativa de sistematizar a administração da Amazônia, especula-se sobre ingerências de potências estrangeiras em uma gama de assuntos internos atrelados à soberania e à segurança nacional. Não estamos preocupados em encontrar a origem, mas sim percorrer algumas redes de significados institucionais que compõem o pensamento político-estratégico sobre a Amazônia. Podemos dizer que as narrativas político-militares sobre a Amazônia se compõem de categorias elaboradas ao longo do processo histórico de governo do território amazônico. Por exemplo, categorias tais como sertão, ameaça internacional, cobiça internacional, conquista, segurança nacional, integração, progresso e desenvolvimento, elaboradas ao longo da história do Brasil, disciplinam a relação entre a sociedade brasileira e a natureza amazônica, ordenando a ocupação e o modo que deveríamos organizar a existência naquele espaço.

\section{Geopolítica militar brasileira: a doutrina da segurança nacional aplicada à Amazônia}

O período que se inicia com a revolução de 1930, levando ao Estado Novo de 1937 a 1945, passando pe-

2 O termo Geopolítica foi pioneiramente empregado, em 1905, por Rudolf Kjellen. Porém, de acordo com Backheuser (1924) e Miyamoto (1981), Friedrich Ratzel ultrapassou a fronteira da Geografia Política, lançando a verdadeira Geopolítica enquanto política estratégica para os Estados. Ratzel exerceu influência direta nas décadas de 1930 e 1940 sobre o establishment do governo alemão. los governos eleitos democraticamente de Getúlio Vargas (1951-1954) e Juscelino Kubitschek (1956-1960), até o governo militar de 1964 a 1985, é de crescente institucionalização de políticas estratégicas para o território amazônico. É na institucionalização de um pensamento geopolítico brasileiro que encontramos com maior clareza indícios de apropriação por parte do aparato político-administrativo de categorias que historicamente foram sendo gestadas para lidar com a complexidade socionatural da Amazônia brasileira. Antes de entrar nas categorias específicas que nos interessam nesse período da história do Brasil, faz-se necessário distinguir dois tipos de produção geopolítica. Podemos dizer que há geopolítica produzida pelo aparato intelectual das Forças Armadas brasileira e geopolítica acadêmica civil. Denomino a primeira de geopolítica militar e a segunda de geopolítica crítica. Esta é mais próxima de uma geografia política que se alinha aos preceitos teórico-práticos de Raffestin (1993) (Pour une Géographie du Pouvoir), Raymond Aron (2002), e se expressa, por exemplo, nos trabalhos de Everaldo Backeuser (1926; 1927; 1933), Bertha Becker (1982), Marília Steinberger (1997), Wanderley Costa (1992), Márcia Anita Sprandel (2005), Elias de Castro (2004), entre outros. Contrasta com a geopolítica militar, que no Brasil se vincula aos trabalhos pioneiros de fronteira de Everardo Backheuser (1926), depois às obras dos generais Golbery (1981a; 1981b; 1967), Góes Monteiro, Mário Travassos (1938) e Meira Mattos (1980) e da professora da Escola Superior de Guerra (ESG) Therezinha de Castro (1999), entre outros. Grosso modo, poderíamos afirmar que estes têm maior aproximação intelectual com Friedrich Ratzel (1898-1899) e Paul Vidal de La Blache (1845-1918). A distinção em termos mais substanciais poderia ser colocada do seguinte modo: a geopolítica militar se preocupa mais com uma política de poder de Estado nacional; diferentemente, a geopolítica crítica se preocupa em compreender políticas territoriais e suas composições socioeconômicas. Essa distinção é puramente didática e, em última instância, é convencional.

Márcia Anita Sprandel (2005) analisa de que modo concepções geopolíticas fundamentam planejamentos do Estado brasileiro. Sprandel traça uma genealogia entre concepções geopolíticas e as reflexões de agentes públicos que classificam as discussões de fronteiras do Brasil como uma questão primordialmente geopolítica. Ela constata que há forte matriz militar e geográfica nas ações e reflexões da diplomacia brasileira. Em última instância, há 
uma marcada confluência entre as ações e reflexões da diplomacia e dos militares brasileiros. Sprandel (2005, p. 154) constata que:

\begin{abstract}
Hoje posso dizer, com certeza, que os militares, diplomatas e geógrafos brasileiros que produziram reflexões sobre nossas fronteiras beberam em águas das geopolíticas alemã e francesa. Mais do que isso, que a geopolítica foi fundamental nos seus planejamentos, sempre que estiveram em posições de poder. A análise da produção mais recente (década de 1970) sobre o tema demonstra, outrossim, uma permanência do pensamento geopolítico nos meios militares e diplomáticos nacionais.
\end{abstract}

Márcia Anita Sprandel reconstruiu, no período da primeira república, a linhagem prático-intelectual das políticas para a fronteira do Estado brasileiro e sua conexão com a geopolítica alemã de Friedrich Ratzel (1844-1904) e de Rudolf Kjellén (1864-1922), a francesa de Camille Vallaux, Lucien Paul Victor Febvre (18781956) e de Paul Vidal de La Blache (1845-1918), entre outras. Propostas menos conservadoras, como a do geógrafo francês, Jean-Jacques Élisée Reclus (1830-1905), que tendiam a reconhecer a agência de múltiplos atores, infelizmente, não conseguiram muitos adeptos entre formadores de práticas militares, governamentais ou de ações da sociedade civil.

O pensamento geopolítico nacional, enquanto estudo sistematizado foi impulsionado pelas publicações de Everardo Backheuser (1924). As associações, ao longo da história do Brasil, entre políticos e militares para a conquista do poder político, sempre levaram à quebra da disciplina e a fissão das Forças Armadas, como constata Nelson Werneck Sodré (1979). A geopolítica constitui teoria do poder, "apoiada fundamentalmente no território e só tem valor, diz Oliveira S. Ferreira, se utilizar os fatores geográficos na formulação de uma política" (Miyamoto, 1981, p. 7). A dinâmica de uma geopolítica militar que fundamenta pensamento político-administrativo para o governo do território, da natureza e da nação se institui em práticas e categorias historicamente fabricadas para lidar com a complexidade territorial brasileira, em geral, e amazônica, em particular.

Em que pese a institucionalização de práticas e categorias expressas no ordenamento jurídico, o deslocamento do centro dinâmico de como governar o território amazônico - anteriormente estabelecido por fortificações militares, por fluxos migratórios e por tratados internacionais - intensifica-se na década de 1930, quando o governo Vargas incorpora a Amazônia dentro de uma estratégica política de Estado. Primeiro, o governo Vargas lança a Marcha para o Oeste, um plano de integração e colonização (ocupação) dos vazios demográficos, obedecendo diretrizes de um plano denominado Movimento de Reconstrução Nacional. Segundo, face à demanda por borracha, no contexto da Segunda Guerra Mundial e aos acordos estratégicos entre Washington e Rio de Janeiro, o governo executa políticas de mobilização de trabalhadores para a extração de borracha, os soldados da borracha, o que leva à institucionalização do Serviço Especial de Mobilização de Trabalhadores para a Amazônia (Decreto-Lei no ${ }^{\circ} .813$, de 14 de setembro de 1943) (CABREIRA, 1996).

O processo de integração e colonização é intensificado na década de 1950, quando o desenvolvimento constitui meta do governo federal. São emblemáticos os governos de Getúlio Vargas e Juscelino Kubitscheck que executam planos estratégicos de desenvolvimento como condição necessária à segurança nacional em um ambiente institucional democrático. É fato que a preocupação em ocupar áreas pouco povoadas para evitar a perda de território para nações estrangeiras não é privilégio deste período específico, já aparece na colônia e no império durante a defesa brasileira do uti-possidetis. Mas, nesse momento as preocupações se traduzem em institucionalização de ações mais efetivas. Por exemplo, no ano de 1953 o presidente Getúlio Vargas sanciona a lei no 1806 que institui a Superintendência do Plano de Valorização Econômica da Amazônia (SPVEA) e o Fundo de Valorização Econômica da Amazônia. Em 1957, durante o governo Juscelino Kubitschek, sanciona-se a lei de define a mudança da capital para o centro geográfico do país, demanda antiga de doutrinas geopolíticas (CASTRO, 1999; RIBEIRO, 2008). A construção da rodovia Belém-Brasília, dando concretude a um plano de integração entre Norte e Centro-Oeste do país, constitui passo significativo nesse projeto. A rodovia concluída em 1960 favorece fluxo migratório de trabalhadores, principalmente do Nordeste, em busca de terras. Esse processo continua e se intensifica com o governo militar pós-golpe de 1964. Em síntese, esse é o contexto histórico em que se inserem as práticas elaboradas pelos estrategistas militares. Por meio das obras dos generais Mário Travassos, Carlos de Meira Mattos e Golbery do Couto e Silva, é possível analisar as interfaces entre as doutrinas geopolíticas da escola geopolítica militar e as práticas para a Amazônia brasileira. 


\subsection{Mário Travassos: projeção continental do Brasil}

De acordo com Sprandel (2005), Mário Travassos é apontado por Philip Kelly (1988) como sendo o "terceiro numa linha de homens que teriam contribuído para fazer da geopolítica um padrão integrado de pensamento político. Antecedido apenas pelo Barão do Rio Branco e por Everardo Backheuser, lhe seguiriam os generais Silva e Mattos" (2005, p. 171). Seguiremos essa trilha. Mário Travassos é considerado divisor de águas na geopolítica brasileira quando comparado aos trabalhos de Backeuser (1918; 1927; 1932) e Carlos Delgado de Carvalho (18841980), na medida em que Travassos analisa em termos mais pragmáticos a posição político-militar a ser exercida pelo Brasil em termos internacionais.

É no livro Projeção Continental do Brasil (1938), em edição de 1931 com título Aspectos geográficos sul-americanos, que o general Mário Travassos sinaliza para a mudança de papel desempenhado pelo Brasil no continente sul-americano, no Atlântico Sul e no mundo, tendo o espaço e a posição como pontos fundamentais para a análise dele. Trata-se de uma análise geopolítica do território nacional, focando nas potencialidades geográficas que o território apresenta. Grosso modo, Travassos se preocupa com o controle físico-político (militar-econômico) do subcontinente americano e as potencialidades marítimas do Atlântico e do Pacífico. Quanto maior o número de saída, maiores as possibilidades de controle de áreas vitais. Para planejar a projetação estratégica do poder brasileiro na América do Sul, ele divide sua análise espacialmente em dois pares de oposição: Atlântico versus Pacífico; Prata versus Amazonas. Traduzir politicamente as vantagens da unidade geográfica que o Brasil goza é o desafio, segundo Travassos, do plano de projetar geopoliticamente o Brasil. O estado de Mato Grosso, no Brasil, e a Bolívia são a posição geográfica central do continente e, para ele, "onde se cruzam os mais graves problemas decorrentes da composição entre o Prata e o Amazonas" (TRAVASSOS, 1938, p. 236). Segundo Travassos, a região amazônica poderia neutralizar a influência argentina na Bolívia, nos Andes e no Pacífico, porque o Brasil conseguiria escoar pelas águas da Bacia Amazônica as riquezas do planalto boliviano que também possibilitariam a abertura do Pacífico ao Brasil. Geograficamente, a unidade territorial nacional se garantiria pela convergência ao centro geográfico do continente das duas grandes regiões Amazônica e Platina. Ao planalto mato-grossense e no altiplano boliviano, restariam apenas traduzir essas dire- trizes estratégicas em ações políticas. A unidade nacional estaria assegurada pela dinâmica política e econômica do centro geográfico do continente (TRAVASSOS, 1938, p. 130-133).

Garantido isso, segundo Travassos, a crescente territorialização de ativos norte-americanos na América do Sul se torna outro desafio. Para ele a influência norte-americana se realiza principalmente por causa do "fracionamento político do território sul-americano". O Brasil deveria promover estrategicamente um fortalecimento político-institucional da região. Antes, contudo, seria imprescindível colocar em ação um projeto de Brasil longitudinal que conectasse, por meio de redes de transportes terrestres e aéreos, redes de telecomunicação e integração econômica, as regiões naturais do Brasil. O fortalecimento socioeconômico do país iria promover sua projetação no subcontinente sul-americano. Comparando o território sul-americano ao norte-americano, Travassos (1938, p. 191-192) delineia seu projeto:

Enquanto que no continente norte-americano ele se define claramente pela simples ligação entre dois grandes oceanos, desenvolvendo-se as linhas terrestres em território sob uma mesma bandeira e orientados, em sua maior extensão, no sentido dos paralelos, o mesmo não se verifica quando se trata da massa continental sul-americana. Essa massa se orienta principalmente no sentido dos meridianos e sobre ela se exercem as atrações dos mesmos oceanos, mas através de territórios sob diversas bandeiras. Isso conduz, no que respeita a transcontinentais, a desdobrar-se desde logo o problema, distinguindo-se as linhas transversais, de oceano a oceano, das linhas longitudinais. Assim encaradas, desde logo, a solução do problema, verifica-se que as transcontinentais sendo os paralelos respondem a necessidade econômicas, do mesmo modo que as que se orientam segundo os meridianos respondem a tendências políticas

As ligações transversais levam a conduções de mão dupla, tanto a saída para o Atlântico dos países andinos (Chile, Peru, Equador e Colômbia) quanto a saída para o Pacífico para o Brasil, Argentina e Uruguai, além de beneficiar os países mediterrâneos (Bolívia e Paraguai). É a integração econômica sul-americana tendo o Brasil como líder desse processo que visa uma "marcha para oeste" que integraria o interior ao litoral, projetando o Brasil no continente.

Contextualizando historicamente a incorporação da geopolítica nas instituições estatais, podemos verificar algumas implicações desse movimento. Primeiro, a geopolítica fazia parte das projeções políticas de setores 
militares brasileiros. Durante o regime militar, projeções geopolíticas justificaram construções de grandes obras (por exemplo, hidrelétrica binacional de Itaipu e a rodovia Transamazônica). Mário Travassos, na essência de seu pensamento, projetava o Brasil à posição de maior potência no cenário sul-americano, traçando grandes rumos para uma política nacional (SPRANDEL, 2005).

Estabelecidas as diretrizes geopolíticas para uma hegemonia brasileira no subcontinente, Travassos vê a influência "Yankee" na bacia amazônica como negativa para os interesses brasileiros. Tendo como exemplo a política norte-americana para o canal do Panamá e a Nicarágua, Travassos aponta para os interesses político-econômicos que se concretizariam na indústria da borracha, da mineração e do petróleo. Ele diz que a "esses imperativos respondem o controle exercido pelos americanos sobre o petróleo da Venezuela, da Colômbia e do Peru e a atuação da Ford na Amazônia" (TRAVASSOS, 1947, p. 78). A exploração da borracha, a entrada do Brasil na Segunda Guerra Mundial, a aliança estratégica com os EUA para neutralização da ação alemã e italiana no Atlântico Sul, entre outros, foram ao longo do século XX fatos que sinalizaram para o fortalecimento da presença norte-americana na América do Sul. O risco territorial que a Amazônia correria desde 1945 seria de outra ordem, ou seja, seria estar no raio de atuação do aparato político-militar e empresarial dos EUA. Em contrapartida, a proposta de proteção estaria em projetar o poder socioeconômico brasileiro sobre a massa continental sul-americana.

\subsection{Golbery do Couto e Silva (1910 - 1987)}

Boris Fausto (2002, p. 635) faz uma pequena biografia de Golbery do Couto e Silva nos seguintes termos:

[...] militar, membro da Escola Superior de Guerra desde 1952, consolidou a doutrina de segurança nacional que serviria de fundamento ideológico para a ditadura militar. Ajudou a articular o golpe de 1964, criando a seguir o SNI, que passou a chefiar com status de ministro até 1967. Presidiu o Dow Chemical para a América Latina (1972). A partir de 1974 chefiou o Gabinete Civil da presidência. Renunciou em 1981, por ocasião do episódio do Riocentro.

Em 1955, Golbery publica Aspectos geopolíticos do Brasil (reeditado com o título de Geopolítica do Brasil, em 1967), em que delineia projeto político para ações internas e internacionais do Brasil. Ideólogo da doutrina da segurança nacional (herdeiro de Góes Monteiro), elaborada com base em reflexões conservadoras sobre a conjuntura política nacional e internacional, Golbery do Couto e Silva tornou-se intelectual reconhecido dentro e fora dos circuitos militares. Ele manteve forte presença no cenário político-militar brasileiro desde a década de 1960. É apontado por Boris Fausto (2002) como um dos articuladores do golpe de 1964. Depois, em cooperação com o general-presidente Ernesto Geisel, Golbery planeja a distensão para uma redemocratização motivada tanto pelos intensos conflitos internos das Forças Armadas (grupos dissidentes de direita e esquerda) quanto pela crescente oposição ao regime por parte da sociedade civil (GASPARI, 2002). Golbery também é apontado como principal idealizador e primeiro chefe do Serviço Nacional de Informações (SNI). Exerceu o cargo de chefe da Casa Militar dos presidentes Ernesto Geisel (1974-1979) e Figueiredo (1979-1985). No contexto das disputas ideológicas da Guerra Fria, as forças armadas edificaram a doutrina da segurança nacional, gestada no âmbito da Escola Superior de Guerra (ESG), fundada em agosto de 1949, apoiada por conselheiros norte-americanos e franceses $^{3}$. De acordo com Boris Fausto (2002, p. 453):

[...] o general Cordeiro de Farias teve papel de relevo na formação da escola [ESG]. Mas sua principal figura, como técnico e organizador, foi o general Golbery do Couto e Silva [...]. De um modo geral, podemos dizer que a partir da ESG e de órgãos como o Instituto de Pesquisas e Estudos Sociais (IPES) e do [...] IBAD [Instituto Brasileiro de Ação Democrática] foram surgindo as linhas definidoras de um regime político considerado capaz de impedir a subversão da ordem e garantir um certo tipo de desenvolvimento econômico ${ }^{4}$.

Golbery conseguiu transformar parte de suas reflexões geopolíticas em ações políticas durante o governo militar pós-golpe de 1964. Em Geopolítica do Brasil (1967), Golbery fundamenta suas ideias no pressuposto de que um determinado nacionalismo poderia unir a todos em torno de objetivos nacionais permanentes. Esses deveriam sintetizar aspirações e interesses de toda coletividade nacional em torno de ideais de liberdade,

3 A ESG foi inspirada nos War Colleges norte-americanos, onde estudavam militares de toda América Latina. A Escola Superior de Guerra apesar do nome, não se trata de uma escola voltada aos assuntos clássicos da Estratégia e da Tática. Seus estudos são voltados para a política, sendo que seu principal curso, o Curso de Altos Estudos de Política e Estratégia, tem, desde a sua fundação, em seu corpo discente mais da metade de alunos civis (BRAGA, 2002).

4 Para a ligação do IBAD com a Agência de Inteligência Norte-Americana (CIA), ver Dreifuss (1987). 
segurança e bem-estar. Parece paradoxal que um dos articuladores do golpe militar, reconheça como uma das aspirações nacionais a liberdade. Mas, para ele, no contexto da polarização entre o capitalismo norte-americano e o socialismo soviético, ${ }^{5}$ liberdade significava garantir a propriedade enquanto um direito civil. Dentro do esquema analítico de Golbery, o ponto de confluência para se definir os objetivos nacionais associava-se à definição de nacionalismo. Nas palavras dele:

[...] o nacionalismo é, ainda, toda a nossa nobreza. E, se não o for conscientemente, muito importante que o seja. Sem dúvida, o homem ente social ou político como já definido, foi e sempre será o polo de uma hierarquia de lealdades - freqüentes vezes, palco íntimo de dilaceradores conflitos entre lealdades diferentes [...] Ser nacionalista é reconhecer, como suprema lealdade, a lealdade à nação de que se é ínfima parte, mas parcela atuante e consciente. Ser nacionalista é sobrepor, portanto, a quaisquer interesses outros, individuais ou de facções ou de grupos, a quaisquer vantagens regionalistas ou paroquiais, os verdadeiros interesses da nacionalidade. Ser nacionalista é estar sempre pronto a sacrificar qualquer doutrina, qualquer teoria, qualquer ideologia, sentimentos, paixões, ideais e valores, quando quer se evidenciem nocivos e de fato incompatíveis ante a lealdade suprema que se deve dedicar, sobretudo, à nação. $\mathrm{O}$ nacionalismo é, portanto, deve ser, só pode ser um absoluto, em si mesmo um fim último pelo menos enquanto perdurar a nação como tal. Lugar não há, nem deve haver, nem poderá haver para o nacionalismo como simples instrumento de um fim que o transcenda, como degrau apenas numa escala que o transmonte. Isso nunca será nacionalismo - será engano, será burla, será até mesmo chantagem [...] Esse, o nacionalismo sadio que deve inspirar, motivar, permear toda elaboração política, toda concepção estratégica, toda formulação geopolítica (SILVA, 1967, p. 96-101).

O nacionalismo é etnocêntrico, caso contrário não fundaria um sentimento de pertencimento que envolve os indivíduos em algo maior do que eles próprios e melhor do que os outros. De maneira geral, é esse sentimento nacionalista que fundamenta a doutrina da Segurança Nacional e da Soberania que impactam diretamente o modo como os governos militares pós-1964 enfocaram a questão amazônica. Golbery acredita que a observância de um nacionalismo de boa índole, signifi-

Deixaremos de lado as concepções de "guerra total" que se fundamentavam na conjuntura da guerra fria e da corrida armamentista polarizada entre as potências nucleares, EUA e União Soviética. cando anticomunista e "pró-desenvolvimento econômico aos moldes do capitalismo tradicional", levariam aos adequados objetivos nacionais permanentes. Apesar de delinear com precisão a dominação de uma elite dirigente (SILVA, 1967, p. 11), ele reconhece que essa teoria das elites é acessória. O fato primordial "é que cada Estado se move ao impulso potente de um núcleo de aspirações e interesses, mais ou menos definidos com precisão num complexo hierárquico de objetivos" (SILVA, 1967, p. 11). A geopolítica de Golbery parte desses objetivos nacionais que em termos gerais remetem à "persistência de todo o grupo social, do Estado e da Nação como tais - isto é, à sua sobrevivência no espaço e no tempo, sua autonomia em relação aos demais e o próprio desenvolvimento econômico e social" (SILVA, 1967, p. 11). Para Golbery cada Estado propugna por seus próprios objetivos que estão fundamentados "num código moral predominantemente egoísta" (SILVA, 1967, p. 11) dentro do ambiente anárquico das relações internacionais envolta no formalismo de tratados e convenções "pouco duráveis".

Silva (1967, p. 13) pretende delinear a direção dos esforços institucionais dentro de um projeto de Poder Nacional que se potencializa na execução de ações estratégicas integradoras de todos os recursos físicos e humanos de que dispõe o Estado nacional brasileiro, "da capacidade espiritual e material, da totalidade de meios econômicos, políticos, psicossociais e militares que possa reunir para a luta”. Lutar contra quem e o quê? Em princípio, a luta é contra as ameaças comunistas e os "inimigos internos". Depois, a luta é em prol de um desenvolvimento que iria garantir a integração e a segurança nacional. Dentro de um ethos militar do sacrifício em prol de uma causa maior, Golbery invoca a nação a resolver o dilema do Bem-estar versus Segurança com base numa política de Segurança Nacional. Ele decompõe diretrizes governamentais em quatro estratégias (política, econômica, psicossocial e militar) que garantiriam a segurança nacional.

As diretrizes geopolíticas traçadas por Golbery propõem a humanização, integração e valorização do território. Limitando-nos às questões voltadas para a Amazônia, na terceira fase das manobras geopolíticas propostas, o plano esboça o seguinte: $3^{\text {a }}$ fase - inundar de civilização a Hileia amazônica, a coberto dos nódulos fronteiriços, partindo de uma base avançada constituída no Centro-Oeste, em ação coordenada com a progressão E.-O. segundo o êxito do grande rio (SILVA, 1967, p. 132). 
Ao detalhar mais essa terceira fase das diretrizes geopolíticas, identificamos o plano de conquista da Amazônia traçado mediante a execução de grandes obras de infraestrutura, tais como estradas:

\begin{abstract}
A $3^{\text {a }}$ fase, de conquista da Amazônia, exigirá que se tome pé firme no segundo heartland do interior, para a concretização do grande esquema de manobra, concêntrico em todo um largo e importante primeiro tempo, e a seguir divergente a partir do polo capital de Manaus. A valia inigualável dos cursos de água nem precisa ser aí ressaltadas, desde o Guaporé, demarcando lateralmente a fronteira, até os múltiplos afluentes penetrantes do Amazonas. A Transacriana (BR-364), antevista por Euclides da Cunha, merece aqui especial referência, não seja acaso possível considerá-la como elemento essencial do próprio tamponamento inicial da fronteira. Se atentarmos para que, à medida de tudo isso, haverá que prosseguir na incorporação paulatina dos diversos maciços atlânticos de terras, o que se traduzirá em articulações internas convenientes para cada um, no povoamento e colonização, na exploração racionais dos recursos naturais - teremos pálida ideia do ingente vulto de toda a obra a concretizar para que o Brasil venha a ser, afinal, o 'colosso do Sul', como almejamos confiantes (SILVA, 1967, p. 133-134).
\end{abstract}

De acordo com esse plano, a Segurança Nacional se faz mediante uma territorialização do Estado nacional que implique em domínio efetivo, claramente marcado por fluxos migratórios, intensa integração de atividades econômicas aos centros dinâmicos do país. Na perspectiva dos executores de um plano nacional de segurança, é necessária garantia mínima de dominação brasileira incrustada no território nacional. Para tanto, o Estado proporciona à coletividade nacional a consecução e salvaguarda de seu Poder Nacional, a despeito dos antagonismos internos ou externos, existentes ou presumíveis. As indicações de Golbery apontam para uma rearticulação do território que estimulasse a ampla manobra estratégica, objetivando a integração definitiva e o desenvolvimento de todo o espaço nacional. É nesse contexto de articulações políticas que para Golbery a Geopolítica se converte numa arte, a arte de guiar a prática política (SILVA, 1967, p. 155).

\subsection{General Meira Mattos: Pan-Amazônia}

O General Meira Mattos é considerado pela crítica especializada em estudos estratégicos (MIYAMOTO, 1981; ÁLVARES, 1973), o estrategista que conseguiu deslocar, dentro das concepções geopolíticas do Brasil, os eixos de tensões do Cone Sul (Rio da Prata) para a
Amazônia (Bacia do Amazonas). Para Meira Mattos, a geopolítica se enquadra no campo das ciências, como um ordenamento de uma reflexão normativa que busca apreender as relações entre política e geografia, dentro de disciplinas como Geografia Humana (ou Antropogeografia) e a Geografia Política, sendo a geopolítica a marca da vontade política expressa em espaços geográficos, i.e., o poder de decidir sobre os espaços. A concepção de geopolítica proposta por este autor é relativamente simples: "é a política aplicada aos espaços geográficos" (MATTOS, 1980, p. 160). É justamente essa conceituação que leva Mattos a argumentar a favor do Tratado de Cooperação Amazônica como o melhor meio de proteger as soberanias nacionais de armadilhas político-militares de grandes potências econômicas e militares não amazônicas. No caso da Amazônia brasileira, aplicar a política ao território seria pactuar em torno de diretrizes de desenvolvimento, integração e soberania, possibilitando, nos mesmos termos, a soberania dos outros Estados nacionais que compõem a bacia amazônica.

É nesse contexto que Mattos problematiza a Amazônia. Ao elaborar o conceito de Pan-Amazônia, ele identifica a diversidade política que envolve o que considera uma macrounidade natural, mas não política. Ele elabora uma análise complexa da Pan-Amazônia enquanto uma "macrounidade, onde se integram espaços geográficos, condições climáticas, província botânica, bacia hidrográfica e característica socioeconômica" (MATTOS, 1980, p. 5). Mattos não realiza uma análise conservadora para fundamentar seus argumentos em torno de uma geopolítica pan-amazônica, ele procura delimitar objetivos específicos de integração e desenvolvimento que associem os Estados nacionais em projetos comuns. Ele exemplifica de que modo tornar o desenvolvimento um processo emancipador de povos indígenas, ribeirinhos, todos integrados a dinâmicas que movimentassem redes de trocas entre os seis países membros da bacia amazônica.

Politicamente, a Pan-Amazônia começa a criar sua concretude no Tratado de Cooperação Amazônica, assinado em Brasília, em 3 de julho de 1978, pelos oito países amazônicos (Bolívia, Brasil, Colômbia, Equador, Guiana, Peru, Suriname e Venezuela ${ }^{6}$ ). O acordo tem ca-

${ }^{6}$ O território francês, Guiana Francesa, não faz parte do tratado. 
ráter geopolítico de proteção e de integração econômica da região, teve forte articulação diplomática brasileira, sendo um tratado mais identificado com preocupações brasileiras. Mattos destaca cinco princípios fundamentais que dão sustentação aos interesses comuns: (1) são de competência exclusiva dos países da Região o desenvolvimento e a proteção da Amazônia; (2) respeitar-se-á a soberania nacional na utilização e preservação dos recursos naturais de cada Estado; (3) a cooperação regional exerce papel fundamental para induzir o desenvolvimento e a preservação; (4) buscar-se-á o equilíbrio e a harmonia entre o desenvolvimento e a proteção ambiental, o que os geopolíticos militares habitualmente denominam de exploração racional de recursos naturais; e (5) absoluta igualdade entre os parceiros (MATTOS, 1980, p. 122). A Pan-Amazônia à que se refere Mattos advém de uma perspectiva totalizante da Amazônia e não de práticas nacionais sobre seus pedaços particulares da região. Ele afirma que

[...] as palavras Amazônia e pan-amazônia deveriam simbolizar a mesma imagem geográfica. $\mathrm{Na}$ realidade isto não acontece. Esta imensa região natural, portadora de ecologia uniforme, abrangendo o território de seis países tributários, é enfocada por seus condôminos sob uma visão particularizada. Assim é que quando o brasileiro ou o venezuelano, colombiano, peruano, equatoriano ou boliviano refere-se à Amazônia está falando na sua Amazônia nacional (MATTOS, 1980, p. 122).

Para Mattos (1980), de acordo com concepções hidrográficas, as Guianas não fazem parte da Amazônia porque seus territórios estão fora da bacia, separados pela parede do maciço guianês. Contudo, de acordo com o Tenente-Coronel Tocantins que escreveu o prefácio do livro:

[...] Ge General Meira Mattos reconhece a justa preponderância dos fatos ecológicos que devem nortear estudos e execução da política de integração pan-nacional e pan-americana das Amazônias que compõem o quadro fisiográfico sul-americano. Ele é sensível à análise geopolítica na justa medida dos princípios da escola da Ecologia Política (White, Renner, Van Walkemburg), que o General Golbery define: 'estudo dos ajustamentos político-geográficos e sociais ao meio natural, com interpenetração geográfica das relações internacionais (MATTOS, 1980, p. 17).

Ele classifica a Pan-Amazônia como uma macrounidade composta pela grande planície Pan-amazônica, abrindo-se em leque de leste para oeste, circundada ao norte pelas vertentes do maciço das Guianas, ao sul pelos degraus descendentes do planalto central brasileiro e a oeste pelos peneplanos da cordilheira andina, formando uma macrounidade, onde se integram espaços geográficos, condições climáticas, província botânica, bacia hidrográfica e características socioeconômicas (MATTOS, 1980, p. 23). Comparativamente:

[...] a bacia abrange a extensão enorme de 7 milhões de $\mathrm{Km}^{2}$, duas vezes maior que a do Mississipi (3,2 milhões de $\mathrm{Km}^{2}$ ) e duas vezes e meia maior que a do Nilo $\left(2,8\right.$ milhões de $\left.\mathrm{Km}^{2}\right)$. O que mais impressiona nessa imensidão é a espessa floresta latifoliada tropical, do tipo hileia, de grande extensão e homogeneidade panorâmica, cobrindo $70 \%$ de toda a região. A cobertura vegetal restante, localizada nas ladeiras das cordilheiras e do planalto brasileiro, é composta por floresta mistas de transição, zonas de cocais, cerrados e savanas (MATTOS, 1980, p. 23).

Apesar de não realizar um levantamento exaustivo, Mattos se preocupa em incluir em sua geopolítica pan-amazônica as elaborações de autores de países amazônicos, dentre os quais se destacam o escritor e político peruano Vargas Llosa (A Casa Verde), o escritor boliviano Aguirre Aché (De los Andes al Amazonas), o ministro das relações exteriores venezuelano José Alberto Zambrano, o sociólogo e político equatoriano Julio Enrique Vela. Para identificar a atração que a Pan-Amazônia exerce sobre a comunidade científica mundial, Mattos nomeia parte dos naturalistas, botânicos, geógrafos, historiadores e cientistas sociais da Europa e dos EUA que realizaram trabalhos sobre a região nos séculos XVIII, XIX e XX tais como: Charles Marie de La Condamine (1771-1774); Von Martius (1794 -1868); Alcide D’Orbigny (1802-1857); Louis Agassiz (1807-1873); Alfred Russel Wallace (18231913); Charles Hartt (1840-1878); Orvile Derby (18511915); Jules Crevaux (1847-1882); Koch Grunberg (18721924); Lévi-Strauss; Curt Nimuendaju; Paul de Cointe; A. Metraux; Pierre Gourou; Pierre Deffontaines; Harold Sioli; Ernest Fittkau; H. Klinge. Essa preocupação em levar em consideração diferentes modos de lidar com a questão amazônica e de suas unidades nacionais expressa o esforço de Mattos de não se limitar a uma perspectiva exclusivamente nacionalista brasileira tampouco a um etnocentrismo estéril. Conduzido por um pragmatismo consciente da pluralidade de ordenamentos institucionais que governam a Pan-Amazônia, Mattos se esforça em buscar traçar um plano estratégico que assegure institucionalmente as soberanias nacionais dos países amazônicos.

Dentro da lógica geopolítica elaborada por Mattos, o pacto amazônico entre os países da região serve 
também para rechaçar "os desígnios de interferência do gênero do defunto Pacto da Hiléia ou do mais recente Projeto dos Lagos. Nessa ordem de preocupação, a regionalização ou consagração da vocação regional da Amazônia é o melhor antídoto para coibir o aparecimento de modernas reencarnações da desmoralizada, mas persistente manobra da internacionalização" (MATTOS, 1980, p. 122-123, grifo nosso). ${ }^{7}$ Pragmaticamente, Mattos se preocupa em manter claro que o Tratado de Cooperação Amazônica é para manter "o contorno das esferas de soberania. Não se intenciona, de forma alguma, superpor critérios multinacionais aos nacionais. Ao contrário, proclama-se que o esforço interno continuará a ser o fator primordial no desenvolvimento dos territórios amazônicos" (MATTOS, 1980, p. 123). Para ele, antes que as potências mundiais - como no caso da tentativa de fundação do Instituto Internacional da Hileia Amazônica, mediante o Acordo de Iquitos - impusessem obrigações de cooperações e limitassem soberanias, deixando "uma porta aberta para o conhecido projeto de internacionalização da Amazônia, embalado pelas grandes potências" (MATTOS, 1980, p. 124) era preciso vincular os países da região em torno de diretrizes comuns, o que fortaleceria a segurança comum. Contra a proposta do Instituto Internacional da Hiléia, Mattos (1980, p. 124) argumenta:

\begin{abstract}
Mais uma vez, quando da assinatura do Acordo de Iquitos, defendido pela candura de nosso representante na UNESCO, o cientista Paulo Carneiro, e aqui pelo jornalista Carlos Lacerda, levantaram-se em oposição as vozes esclarecidas e vigilantes de expressivos valores do nosso Parlamento, da imprensa e da diplomacia, e o Acordo, afinal, não foi ratificado pelo nosso Congresso. Salvamo-nos do perigo de entregar a gestão de assuntos amazônicos a europeus, norte-americanos e asiáticos. O Instituto da Hileia Amazônica seria realmente um condomínio internacional e uma autêntica desapropriação da região em benefício de programas extranacionais e supranacionais. Talvez, veladamente, viesse a responder ao desejo, algumas
\end{abstract}

Tanto o Pacto da Hileia quanto o Projeto Lagos são tentativas de articulação política para se executar programas amplos de financiamentos, de ajuda humanitária e de preservação ambiental, para a região amazônica. Especificamente, o projeto lagos teve uma maior elaboração teórica do Instituto Hudson (EUA) e causou uma enorme repercussão na mídia e os setores envolvidos com políticas estratégicas e geopolíticas no Brasil. Por sua vez, o Pacto Hiléia nasceu com a proposta da UNESCO de fundar o Instituto de Internacional da Hileia Amazônica. Também muito combatida por setores militares brasileiros. vezes manifestado, em foros internacionais, de transformar a Amazônia numa grande área-reserva de desafogo dos excessos populacionais de outras regiões. Se aceitássemos a Hileia internacional da UNESCO, estaríamos abdicando de direitos soberanos que, como sabemos, são indivisíveis; não existe meia-soberania, nem soberania parcial.

Mattos defende uma maior integração entre o sistema de transporte, de circulação de mercadorias e de cooperação entre os países amazônicos. Isso beneficiaria não só o Brasil, mas toda a região e seria, no argumento dele, a melhor solução para defender a Amazônia. O Tratado de Cooperação Amazônica, nessa perspectiva, consiste em instrumento para integrar os países amazônicos em torno de objetivos comuns, rechaçando iniciativas que afetassem as soberanias nacionais. Mattos ressalta a importância da ecologia no do tratado, apontando para novas concepções de preservação, prevendo o crescimento das questões ecológicas que já se colocavam desde a década de 1970. Ele concebe a Amazônia com expressão do destino manifesto de continentalidade do Brasil, a interiorização, ou seja, a marcha da fronteira econômica para o oeste deveria ser concretizada para completar o plano geopolítico de segurança do Estado nacional brasileiro.

A proposta estratégica Pan-Amazônica de Mattos abre mão de pretensões expansionistas, no sentido da predominância política do Brasil na região, em prol de uma integração sólida, assegurando um pacto pela defesa da região pelos países amazônicos e suas soberanias nacionais. É nesse sentido que a geopolítica preconizada por Meira Mattos estabelece três áreas-polos de referência para a integração e expansão do território amazônico à institucionalização político-econômica dos países do pacto amazônico: sistema Solimões-Juruá (Brasil, Colômbia e Peru); sistema Negro-Branco (Brasil, Guiana, Venezuela, Colômbia); sistema Madeira e sistema Purus (Brasil, Peru, Bolívia). Ele traça linhas estratégicas para efetivar a "implantação de polos de irradiação, que assegure a progressão sucessiva dessas frentes com a preservação ecológica dentro de um conceito tradicional e o respeito às reservas indígenas" (MATTOS, 1980, p. 17).

Deixando Uma Geopolítica Pan-Amazônica (1980) para seguir na busca por categorias que instituíram um modo de lidar com a Amazônia brasileira, ao longo do processo de territorialização do espaço analisado neste artigo, passemos para a obra Estratégias Militares Dominantes (1986). Logo na epígrafe do primeiro 
capítulo "A Guerra - uma cosmovisão filosófica", o general Meira Mattos faz duas citações que dão o tom de sua política estratégica militar: Quem prega a guerra é um apóstolo do demônio (JOHN RAY, Provérbios Ingleses).

Resultou disso que todos os profetas armados venceram e os desarmados pereceram (MAQUIAVEL, II Príncipe, cap. 6).

Os dois trechos sintetizam o que Mattos pretende evitar, a derrota, e o que ele quer garantir, a paz. Mattos demonstra intimidade intelectual com a filosofia política europeia, citando Hobbes, Hume, John Locke, Adam Smith, Marx, Schopenhauer, Hegel, Nietzsche, Clausewitz, (séculos XVII a XIX) e alguns cientistas sociais mais contemporâneos, Raymond Aron, Anatole Rappoport e André Glucksmann. Mattos quer atualizar em termos da sociedade da técnica e das complexas relações econômicas e internacionais as constatações acerca da guerra de Clausewitz: "a guerra é um instrumento da política nacional", correlacionada com diretrizes traçadas no século V A.C. por Sun Tzu (A Arte da Guerra) sobre estratégias de dominação, "o bom estrategista é aquele que é capaz de derrotar o inimigo sem atacá-lo, de ocupar as cidades inimigas sem destruir os seus bens, de ocupar seu território sem necessidade de choques sangrentos" (MATTOS, 1986, p. 4). Mattos define política e estratégia como correlatos. Ele diz que política é a arte de governar, ao passo que estratégia é a arte de executar a política, i.e., "política é a concepção de governo e Estratégia é a ação decorrente desta concepção. Política é o que fazer; Estratégia, como fazer" (MATTOS, 1986, p. 7). Mattos dá um passo adiante quando se preocupa com os aspectos simbólicos que norteiam um Estado nacional. Um povo pode ser dominado por um sistema de ideias e valores que venham de outro Estado.

Relacionando essas construções teórico-metodológicas à Amazônia, Mattos (1986, p. 88-89) propõe uma estratégia militar brasileira

[...] do ponto de vista geoestratégico podemos distinguir duas regiões amazônicas: a chamada Amazônia Oriental, gravitando em torno de Belém e São Luís, projetando-se para o segmento nordeste do nosso Atlântico, onde as forças da maritimidade predominam sobre a continentalidade. A atração do mar, aí, se faz sempre presente. Voltada para fora, para o Caribe, para Gibraltar, para a Europa Ocidental. E a Amazônia Ocidental, onde as influências marítimas chegam muito atenuadas; obrigada a viver seu destino continental, em termos de articulação vial e economia interna, se quiser progredir; voltada para dentro, com seus interesses convergindo e se irradiando de Manaus - polo vivificador das imensas regiões fronteiriças - e, particularmente, das áreas lindeiras de inter-comunicação, Boa Vista, São Gabriel da Cachoeira, Tabatinga, Cruzeiro do Sul, Rio Branco, Porto Velho e Guajará Mirim, com os países vizinhos.

Essa caracterização espacial serve para equacionar a estratégia militar de defesa que implica ocupação, adensamento populacional, integração por transportes, desenvolvimento aproximando dos centros dinâmicos da econômica nacional. Na perspectiva dele, sobre esse imenso vazio demográfico $(2 \mathrm{hab} / \mathrm{km}$, a média brasileira é de $16 \mathrm{hab} / \mathrm{km}$, do México é de $34 \mathrm{hab} / \mathrm{km}$, Índia $190 \mathrm{hab} / \mathrm{km}$ ) deve ser projetada uma política estratégica militar nos seguintes termos. As duas regiões geoestratégicas (Amazônia Oriental e Amazônia Ocidental) giram em torno de geoestratégias diferentes, a saber: a Oriental deve concentrar esforços aeronavais, defesa do litoral, dos portos, defesa contra as penetrações (principalmente pelo rio Amazonas), vigilância nas fronteiras terrestres e manutenção de uma capacidade de transporte marítimo protegido e de transporte aeroterrestre de médio raio de ação; por sua vez, a Ocidental deve priorizar a vigilância ativa nas regiões fronteiriças, em particular nas regiões de intercomunicação internacional, capacidade de manutenção de uma reserva operacional aeroterrestre e de transporte aéreo e fluvial para áreas tornadas críticas. A pretensão declarada de uma estratégia militar é de uma força de dissuasão, ou seja, a intenção é desencorajar qualquer agressão contra a soberania de Estados nacionais amazônicos. A dissuasão é preventiva. O gasto se justifica pela segurança que proporcionará.

\subsection{Arthur Cezar Ferreira Reis: como combater a cobiça internacional e conquistar a Amazônia para o Brasil?}

Arthur Cezar Ferreira Reis nasceu em Manaus em 1908 e faleceu em 1993. Exerceu o cargo de professor, pesquisador, jornalista, agente político, servidor público. Ferreira Reis ocupou a poltrona $n^{\circ} 39$, destinada a sócios efetivos do Instituto Geográfico e Histórico do Amazonas (IGHA). Ele também exerceu: a chefia da Divisão de Expansão Econômica do Ministério do Trabalho, Indústria e Comércio; a Superintendência do Plano de Valorização Econômica da Amazônia (SPVEA), entre 1953 e 1955, posteriormente transformada na Superintendência do Desenvolvimento da Amazônia (SUDAM); a presidência do Instituto Nacional de Pesquisas da Amazônia (INPA), em 1956; a direção do Departamento de História e Di- 
vulgação do Estado da Guanabara, em 1961; a diretoria do Departamento Nacional da Indústria, do Ministério da Indústria e Comércio, quando atuou como delegado do Brasil junto à Conferência de Comércio e Desenvolvimento das Nações Unidas, em Genebra, em 1964; o cargo de governador do Estado do Amazonas de 24 de junho de 1964 a 31 de janeiro de 1967 (eleito indiretamente pela Assembleia Legislativa do Estado do Amazonas); entre outros cargos (MEIRA, 1993, prefácio).

É provavelmente o ator-autor síntese por ter conseguido articular como ninguém práticas institucionais ao exercício intelectual de temas ligados à geopolítica do Estado para a Amazônia. Em 1930, junto à primeira Comissão Brasileira Demarcadora de Limites, publica Limites e demarcações na Amazônia brasileira. Desde então apresenta ampla produção. Por um lado, profundas análises críticas da situação socioeconômica e ambiental da região. Por outro, assume posição de ideólogo no fronte das batalhas por conceitos, almas, corpos e poder, representando claramente um projeto civilizador, recorrendo às mesmas categorias anteriormente elaboradas, tais como "tornar a Amazônia um espaço útill" "integrado não apenas nas linhas físicas de nosso patrimônio mas, principalmente, na obra de maturidade material e espiritual que nos esforçamos em realizar com êxito" (REIS, 1960, p. 2). O que nos interessa destacar de Ferreira Reis é a capacidade de expressar os principais receios de um imaginário político-institucional brasileiro ao delinear práticas que se enquadram num suposto combate à ameaça eà cobiça internacional.

Arthur Cezar Ferreira Reis, ao longo de sua produção intelectual e profissional, propôs uma releitura da história do Brasil qualificando eventos históricos como: conquista espiritual da Amazônia (REIS, 1972; 1993); ameaça de internacionalização (1965); cobiça internacional (1973). Como pressuposto, num contexto mundial em que se insere a crescente importância estratégica da Amazônia, ele concebe três fatores decisivos: primeiro, a crescente pressão demográfica vinda do exterior; segundo, em decorrência do aumento populacional, um inevitável aumento na demanda por alimentos (ponto central na estratégia dos Estados-nação); por último, mas não menos importante, os interesses econômicos por matéria-prima que projetam uma escassez, constatando que o subsolo amazônico é tido como reserva o que provoca pressão para sua abertura ao capital estrangeiro. A conclusão é que a Amazônia é solução pragmática e fácil para boa parte dessas demandas contemporâneas. Por isso que, estrategicamente, na perspectiva dele, a atenção dos países desenvolvidos estaria direcionada para a Amazônia. Parte dos problemas do planeta poderia ser equacionada pela exploração das potencialidades da região. Para Reis, o Brasil ainda não despertou para essa realidade. Os sucessivos governos brasileiros não a reconhecem. Inevitavelmente as potências militares e econômicas irão encontrar um meio, seja lícito ou ilícito, de lançar mão das potencialidades amazônicas. A convicção dele se baseia nos seguintes argumentos: (1) a Amazônia é um vazio demográfico, podendo absorver o excedente populacional de países superpopulosos; (2) o sistema hidrográfico da região oferece água suficiente para produção em escala planetária de alimentos (grãos, pecuária etc.); (3) as maiores reservas de minerais, madeira e água do mundo estão na Amazônia. Assim, ela é a fronteira natural para garantir o desenvolvimento da humanidade. Se essas potencialidades se realizarem sem a soberania brasileira, as pressões internacionais irão "conduzir a soluções profundamente humilhantes para o Brasil" (REIS, 1973, p. 158), já que o país não faz uso de sua prerrogativa soberana de desenvolver as potencialidades da região.

É na publicação A Amazônia e a Cobiça Internacional (1973) que ele analisa historicamente manifestações explícitas do que denomina de cobiça estrangeira sobre a Amazônia, i.e., os interesses econômicos e geopolíticos de nações desenvolvidas que visam colocar a Amazônia em esquemas estratégicos de expropriação e colonização. É a primeira exposição sistemática da categoria internacionalização. Nas palavras dele:

Ora, na Amazônia - e aí que está o perigo - o espaço físico imenso apresenta-se praticamente aberto aos mais decididos, aos mais ousados. $\mathrm{O}$ chamado imperialismo das nações fortes não é uma página de lirismo. Existe, e não encerrou o seu ciclo de vitalidade. Não pode nem deve ser desmerecido. Pior que ele, no entanto, é a tendência à internacionalização de trechos do mundo, que já se pretende seja operação necessária, uma solução para agasalhar aqueles que não têm onde viver ou reclamam contra a fome que os atormenta. Leia-se para exemplificar, o livro A luta contra a fome, de Robert Brittan. [...] a Amazônia, que, no entender do autor, só pode ser valorizada pela intervenção de organismos do tipo da Hileia Amazônica, que disponham de técnicas, e de capitais internacionais vultosos, sustenta aquela tese ousada, que recebe aplausos, e sobre a qual não estamos querendo acreditar seriamente, do alcance dessa tendência à internacionalização (REIS, 1973, p. 4). 
$\mathrm{Na}$ leitura de Reis da história da formação territorial do Brasil, destacam-se algumas tentativas de potências (militares e econômicas) estrangeiras em dominar territórios amazônicos. Portanto, ao pontuar eventos, analisados com base numa ressignificação de cobiça internacional, ele procura apresentar um padrão que leva a identificar uma constante tentativa de internacionalizar a Amazônia. Podemos dividir a obra em três partes principais. (1) Disputas territoriais na formação do território brasileiro (capítulo 3, "Ingleses, irlandeses e holandeses tentam a primeira sortida"; capítulo 4, "Portugueses e espanhóis disputam o domínio"; capítulo 5, "Os franceses participam da aventura"; capítulo 7, “Os ingleses sugerem a secessão"; capítulo 10, "Os franceses pretendem o Amapá"; capítulo 11, "Os ingleses penetram no Rio Branco". (2) Projetos socioeconômicos para a região como alternativa_estrangeira para dominar a região (capítulo 2, "Mundo tropical e empório de matérias primas"; capítulo 8, "A navegação do Amazonas"; durante os impasses da livre navegação e da exploração da borracha). (3) Estratégias político-militares e econômicas revestidas de expedições científicas para se apossar de recursos amazônicos (capítulo 9, "Expedições científicas escondiam propósitos"; capítulo 15, "A que vinha a expedição Iglésias?"; capítulo 16, “O episódio da Hiléia”; capítulo 17, “A pressão dos interesses universais"). Reis procura pontuar ao longo da história do Brasil de que modo a cobiça internacional se manifesta e de que modo consegue, em alguns momentos, camuflar seus interesses, menos nobres, em ideais humanitários de toda ordem:

Já vimos, através das páginas deste ensaio, que essa cobiça começou no século XVI quando os ingleses, os holandeses e os franceses tentaram possuí-la. Os interesses da humanidade foram sempre alegados pelos que pretenderam dominá-la. Os norte-americanos, quando procuraram forçar o Brasil à abertura do rio ao comércio internacional, falavam a linguagem desse interesse coletivo. Seria criminoso manter fechadas as portas da imensa região, que já àqueles dias parecia compor um campo amplo para a exploração capitalista. Ademais, o Brasil não dispunha de recursos para um empreendimento de vulto como seria o de transformar a Amazônia, no trecho que lhe pertencia, de área, em estado de natureza, em área humanizada, isto é, utilizada em todo o potencial de que parecia dispor (REIS, 1973, p. 247).

Ele quer conscientizar o leitor de que por trás dessas pretensões humanitárias escondem-se intenções políticas que motivam ações concretas de dominação.
Ora, a grande verdade, é que o interesse sobre a Amazônia no exterior não se reduz a querer conhecê-la como espaço exótico ou de produção de alguma matéria-prima, complementar das que o Oriente e a África exportam. É um interesse muito mais vivo, que esconde outros propósitos, propósitos políticos, a que é preciso dar a devida consideração, pois significam perigo e exigem uma política capaz de impedir que se transforme em realidade muito amarga para o Brasil. A Amazônia está sendo considerada como espaço aberto ideal: a) para receber os excedentes populacionais das áreas que padecem devido aqueles excessos; b) para produzir os alimentos de que carecem aquelas multidões fustigadas pela fome inclemente e mortífera; c) para produzir a matéria-prima vegetal, animal e mineral de que carecem os grandes parques industriais do mundo (REIS, 1973, p. 247).

As preocupações estavam direcionadas por uma concepção geopolítica de produção alimentar e de expansão populacional de outras regiões do planeta que poderiam significar fluxos migratórios para a região. Isso, na perspectiva dele, seria o início de perda da soberania brasileira sobre o território amazônico. Dentro de um esquema geopolítico, segurança alimentar é base de qualquer planejamento estratégico que se preocupe com a sobrevivência da nação enquanto entidade independente e soberana na forma de Estado nacional. Complementarmente, havia também constante preocupação com o vazio demográfico. Era uma tese defendida por muitos nas décadas de 1950 e 1960. Reis dá como referência o livro Hungry people and empty lands (1952), de Chandrasekhar.

$\mathrm{Na}$ perspectiva de crise demográfica e de produção alimentar, em que a UNESCO se apresenta como instituição síntese para essas ideias, havia a proposta do Instituto Internacional da Hiléia Amazônica para capitalizar projetos científicos e de desenvolvimento da região. Na argumentação dele:

Se os objetivos científicos datam de outros séculos, a ideia de internacionalização é mais recente. Há apenas quase vinte anos alguns cientistas brasileiros, em boa-fé, propunham a criação de um Instituto Internacional da Hileia Amazônica, destinado a 'promover, conduzir, coordenar e divulgar estudos da mencionada zona geográfica' e ainda 'preparar e acelerar o ulterior progresso dessa região e dos povos a ela vinculados, para o bem-estar da humanidade. Sob os auspícios da UNESCO chegou-se a criar a referida entidade que, no entanto, encontrou, sob a liderança do ex-presidente Arthur Bernardes, forte repulsa do Congresso Brasileiro, o que levou ao abandono do convênio já assinado em Iquitos. Combatido por certos setores da vida pública nacional e acoimado de nacionalista 'estreito e agressivo', fatos posteriores deram razão 
a Arthur Bernardes que justificava sua oposição ao projeto pela 'sua longa experiência ao tratar com o estrangeiro' que sempre procurou 'tirar proveito de sua maior evolução’ (REIS, 1973, p. 217, grifo...).

Ferreira Reis percebe o lado positivo do programa, mas vê também que o convênio, apenas assinado e não ratificado pelos países interessados, era recebido na Europa "como uma oportunidade para expansão de capitais e populações", o que potencialmente deveria ser um ganho para a região se fosse exercida dentro dos limites soberanos de cada uma das nações que compõem a Amazônia. Na leitura dele, as entrelinhas do convênio deixavam ambiguidades e a fundação do Instituto da Hileia Amazônica mais parecia um instrumento eficaz de internacionalização de "regiões potencialmente produtivas cujo desenvolvimento está atualmente impedido porque os homens criaram fronteiras onde realmente as naturais não existem" (BRITAIN, 1955 apud REIS, 1973, p. 217).

Desde as primeiras expedições de portugueses e espanhóis até a pressão de interesses universais que caracterizam a cobiça internacional sobre os recursos naturais da Amazônia, ponto a ponto, a ideia central gira em torno da constatação de que "a economia da Amazônia é uma economia realizada sob práticas primárias, marcada, fundamentalmente, pela extração de produtos florestais" (REIS, 1973, p. 13). É justamente por essa abundância de matéria-prima que Ferreira Reis considera que a Amazônia é um "campo de atração [...] a ser uma reserva para o futuro. E nesse futuro é que está o grande perigo" (REIS, 1973, p. 19). O problema para ele é que o Brasil se vê como nação atlântica e já se viu muitas vezes como nação platina, contudo, "nunca se realizou como nação amazônica” (REIS, 1973, p. 255).

Belém do Pará [...] foi o núcleo de toda essa história que se escreveu visando à posse da Amazônia para o Brasil, portanto núcleo de onde irradiou uma ação política, uma ação social, uma ação econômica e uma ação espiritual. Seu papel, nesse admirável ensaio imperial, foi um papel que lhe assegura situação invejável na história brasileira, tão grande como aquele de São Paulo como fonte de energia criadora para a ampliação territorial do Brasil (REIS, 1965, p. 12).

A Amazônia é uma realização de que nos podemos ufanar, mesmo na condição de ainda área-problema, que desafia iniciativas, programas de Estado, inteligências objetivas, pragmáticas, e impõe deveres especiais ao poder público para que haja uma natureza dominada e possuída efetivamente como parte da civilização que nos distingue (REIS, 1965, p. 12).
A Amazônia tem sido empresa nossa. Disso podemos nos ufanar. Penetramo-la sem desfalecimento. Ocupamo-la politicamente. Revelamo-la no possível. Dela temos extraído, para o bem-estar de outros, muito do que ela possui de útil" (REIS, 1965, p. 10). Continua: "O povoamento da Amazônia não foi realizado com a contribuição do estrangeiro" (REIS, 1965, p. 206).

No livro A Amazônia que os Portugueses Revelaram (1965), Reis dá um acabamento mais completo a sua proposta:

A Amazônia constitui, portanto, ainda, um excelente campo para a indagação, para a curiosidade, para a atenção dos técnicos, dos homens de ciência nos seus empreendimentos e preocupações para revelar, nas suas peculiaridades, as grandes áreas abertas de que dispõe a humanidade para a empresa da conquista, da exploração sistemática e do enriquecimento universal. Não é um espaço sabido nas suas mil particularidades. No caso particular do Brasil, representará cometimento que lhe há de revelar a posse daquela maturidade, essencial à sua ponderância nos quadros da civilização, essa de seu descobrimento realístico. Porque só quando conquistar a Amazônia, incorporando-a definitivamente ao seu processo dinâmico de cultura material e espiritual, é que o Brasil se afirmará, perante o mundo, como potência, capaz de manter-se nessa condição, fundamental à sua própria sobrevivência (REIS, 1965, p. 22).

Ele afirma que o destino dado à Amazônia será o passaporte para o Brasil entrar no mundo desenvolvido. Essa ideia é seguidamente repetida pelos estrategistas. Reis não está preocupado em formular macroestruturas mirabolantes sem considerar a realidade local, de fato, ele se empenha em incorporar à sua análise demandas de grupos e pessoas que habitam o bioma amazônico. Em panorama histórico, ele procura salientar a experiência acumulada da população que legitimou sua ocupação ao longo da colonização luso-brasileira da região que proporcionou uma interação singular com o bioma amazônico

[...] verdades apuradas no realismo da vida diária, experiência consequentemente de todo um caminhar por séculos de ligação com o meio, verdades primárias, por certo, mas que se incorporam aos conhecimentos de natureza fisiográficas e de natureza socioeconômica e estão levando o próprio poder público a abandonar a posição de mero espectador do desenvolvimento isolado, vagaroso, hesitante, da região, para transformar-se no elemento dinamizante desse processo de desenvolvimento, que deve ser apressado, por necessário à própria segurança do país (REIS, 1965, p. 23). 
Contudo, as riquezas produzidas localmente, acumuladas em séculos de fluxos migratórios, ciclos econômicos extrativistas e desenvolvimento do gênio humano no bioma amazônico, não foram suficientes, na perspectiva dele, para projetar a região dentro do cenário nacional. É necessário exercer uma força de desenvolvimento que promova as potencialidades do país. Destacam-se as preocupações institucionais que ele propõe para efeito de planejamento e realização de "um Brasil potência".

A institucionalização da Amazônia brasileira tem grande impulso com a definição da Amazônia Legal, estabelecida pela Lei 1806, de 6 de janeiro de 1953. Reis (1965, p. 24) comenta:

\begin{abstract}
A Amazônia brasileira, para efeito de planejamento econômico e execução do Plano definido nesta lei, abrange a região compreendida pelos Estados do Pará e do Amazonas, pelos territórios federais do Acre, Amapá, Guaporé [hoje, Rondônia] e Rio Branco [hoje Roraima], e ainda, a parte do Estado de Mato Grosso a norte do paralelo $16^{\circ}$, a do Estado de Goiás a norte do paralelo de $13^{\circ}$ [hoje Tocantins], e a do Maranhão a oeste do meridiano $44^{\circ}$ [...]. Basta, porém, para que se compreenda o que passou a constituir a Amazônia legal, registrar secamente: totaliza agora $5.030 .109 \mathrm{~km}^{2}$, isto é, $2 / 3$ do território brasileiro.
\end{abstract}

O projeto de Reis concebe a Amazônia como espaço disponível para a "grande aventura colonial de civilização ou sua política disciplinativa de um mundo interior" (REIS, 1965, p. 30). É pela intervenção técnico-científica no espaço natural que se executará as pretensões de desenvolvimento. Ele continua com sua delimitação empreendedora da obra A Conquista da Amazonas, falando em "esforço tecnicamente conduzido" (REIS, 1965, p. 128):

\begin{abstract}
Por que, sejamos realistas, só quando conquistar a Amazônia, repito, incorporando-a aos seus quadros materiais e espirituais de vida, transformando-a, do estado de natureza em que permanece, num espaço humanizado pela técnica, pelo homem higienizado e vigoroso, em produção constante, intensa e complementar da produção brasileira, revelador tudo isso de que já conseguiu descobri-la, entendê-la e possuí-la, é que o Brasil assumirá o seu grande papel no conjunto das nações fortes, poderosas, capazes de lances decisivos.
\end{abstract}

A crença é de que a eficácia técnica garantiria desenvolvimento adequado para a projeção do Brasil no cenário político-econômico do mundo, promovendo segurança, conquista e dominação da natureza amazônica.

Percorridas as duas décadas de políticas autoritá- rias, orientadas em sua operacionalidade burocrática por pressupostos geopolíticos, é na redemocratização (1989) que se reconfiguram alianças para se defender uma concepção de soberania nacional pouco emancipatória de grupos e pessoas que vivem à margem de seus direitos. Enquanto, na época da ditadura, poder-se-ia ganhar a batalha pela supressão do processo democrático, após a Constituição de 1988, mais e mais, o front é o formalismo jurídico, as convicções que demandam negociações e acordos. Agora é necessário conquistar principalmente almas (convicções) para se ganhar a guerra.

\section{Conclusão: as categorias que consolidam a instrumentalização técnica para o governo do território}

Desde o golpe militar de 1964, a Amazônia brasileira está sujeita a um processo de articulações territoriais que se intensificam. Agora num patamar mais agressivo de ocupação, por meio de políticas demográficas e de desenvolvimento econômico, orientadas por uma estratégia geopolítica de integração regional que tinha sido formulada nas décadas de 1950 e 1960, na Escola Superior de Guerra (ARRUDA, 2000; SILVA, 1967; ALBERT, 1992). Executou-se uma doutrina de desenvolvimento orientada pela doutrina da segurança nacional, por meio de uma série de ações governamentais, tais como Operação Amazônia, Plano de Integração Nacional, entre outros. São, em última instância, políticas territoriais que inscrevem no espaço amazônico práticas técnico-científico-informacionais (SANTOS, 2002), (a) por meio do desenvolvimento de infraestrutura (rodovias; aeroportos; telecomunicações; logística ferroviária e rodoviária para escoamento de produção), assim como (b) por meio de construções de sistemas de monitoramento aéreo por radares (vigilância militar e voos comerciais), mapeamento geológico, identificação da riqueza mineral (BECKER, 1982). De acordo com Berta Becker (1990), no contexto dos anos 1980, a matéria prima amazônica ajudou a diminuir o déficit na balança comercial, já que atraía investimentos estrangeiro para a indústria primário-exportadora. Façanha operada, burocraticamente, por uma engenharia financeiro-administrativa que permitiu alocar incentivos fiscais, créditos subsidiados, capital externo, promovendo a expansão da fronteira econômica, cada vez mais, para o norte e oeste do país, via agronegócio, mineração, madeireiras. Tudo isso politicamente preso a 
um sistema repressor midiático, policial e de inteligência que não dava visibilidade à oposição ou a aniquilava.

Para sistematizar as categorias que dão sentido as práticas territoriais, podemos agrupar seus significados e utilizar seus conteúdos para definir as narrativas político-militares para a Amazônia. Essas categorias projetam uma pretensa governabilidade sobre o território e a natureza amazônica. É nesse sentido que podemos pensar de que modo o poder opera na classificação de espaços socionaturais, pessoas, coletivos e naturais. Nessa perspectiva aglutinamos categorias administrativas que ordenam e disciplinam os territórios em uma determinada direção. A Coroa portuguesa, o Império do Brasil, a República Federativa do Brasil, cada um a seu tempo, tiveram modos específicos de lidar com o espaço amazônico. Pretendia-se garantir terras na América Meridional e súditos para a Coroa portuguesa; garantir a efetiva posse, fundamentada na legitimação do Direito Internacional Público e do uti-possidetis; garantir a efetividade da soberania, da integridade, do desenvolvimento. No período pós-constituição de 1988, surgiram práticas de preservação que tentaram reinventar o modo de lidar com os espaços socionaturais, por meio de articulações entre o terceiro setor, os setores público e privado, equacionando os desafios de concepções ambientalistas e desenvolvimentistas (MEDEIROS, 2012).

Posse - nas discussões para descrever a constituição do espaço amazônico e suas múltiplas territorialidades, posse é uma categoria que percorre longo processo de elaboração e influência de práticas políticas. Disputas de terras no norte e no oeste do Brasil sempre tiveram, em algum nível, vinculadas à posse da terra. Tomar posse da terra significava na Colônia mais terras além-mar para as coroas europeias, maior possibilidade de encontrar riqueza (ouro, prata, madeira, mão de obra). Edificações de fortificações ao longo do vale do Amazonas para garantir a posse eram a estratégia político-militar da Colônia e do Império. Houve uma inflexão durante o segundo Reinado (D. Pedro II) e a primeira República. Já relativamente garantida boa parte da América Meridional, a intenção era negociar acordos com base no uti possidetis. Ou seja, legitimar internacionalmente a posse por uma pretensão de ocupação existente. Tarefa realizada em grande medida pelo Barão do Rio Branco (auxiliado por Euclides da Cunha e Joaquim Nabuco, em negociações específicas). Posse de terra é ter em seu poder os destinos do espaço e das coletividades nela contida (pessoas, recursos natu- rais, fauna e flora). A prática era de criar posse: fazer a posse útil.

Progresso e desenvolvimento - não cabe realizar levantamento amplo dessas categorias que por si só fundam a própria modernidade ocidental e sua pretensão secular de racionalidade (RIBEIRO, 1991). Para servir ao propósito deste artigo, limitar simplificadamente os desdobramentos em práticas governamentais propostas pelos atores-autores acima analisados. Primeiro, é constatar que as duas são, em última instância, correlatas. Mesmo que o progresso tenha uma conotação de processo linear de melhoramento ao passo que desenvolvimento tem uma conotação de crescimento econômico em estruturas de relações macros; ambas categorias se nutrem de convicções de que é possível promover, cada vez mais, uma emancipação humana perante a natureza, baseadas em sistemas simbólicos de legitimidades (políticas), de verdades (técnico-científicas) e de utopias (valorativa/ ideológica). Tavares Bastos (1975) define progresso como prosperidade pública que seria alcançada por práticas governamentais mais liberais, proporcionando o florescimento do comércio no Vale do Amazonas. Numa perspectiva mais crítica, Euclides da Cunha (1995) percebe os descaminhos do progresso ao analisar o regime do aviamento predominante na região amazônica. O progresso precisa ser racionalizado. Não é deixar o grande empreendimento de conquista da Amazônia na mão de particulares, o empreendimento deve ser racionalizado por controle estatal (regulação), para evitar a escravização de cidadãos da república. As práticas de um Estado promotor do desenvolvimento se intensificam com a Revolução de 1930 e o Estado Novo de 1937.

Integração - se refere à mobilidade dentro do território nacional. Dentro das concepções geopolíticas mais recorrentes (de Meira Mattos, Golbery do Couto e Silva e Mário Travassos, representantes da escola geopolítica brasileira), desde a década de 1950, fala-se em sistema de transportes terrestres (ferroviários e rodoviários), aéreos, navais; sistemas de comunicação (telecomunicações, radares, satélites). Portanto, integração é a mobilidade para pessoas, produtos e informação que dinamizaria tanto as trocas comerciais quanto os fluxos migratórios de região a região. Vincula-se a um determinado grau de logística.

Segurança nacional - doutrina vinculada às mudanças institucionais das Forças Armadas brasileiras, principalmente depois da Missão Francesa ao Brasil, em 1919, das Revoltas tenentistas da década de 1920 e 
da Revolução de 1930. Pedro Aurélio de Góes Monteiro, responsável pela Escola Superior de Guerra e pela institucionalização do ensino da geografia militar nos currículos do Exército, contribuiu com as bases da doutrina que seria elaborada na década de 1950 (MIYAMOTO, 1981, p. 89-113). Grosso modo, a doutrina busca fundamentar um plano de proteção e segurança que não se limita ao território, mas se estende à própria coletividade e seus objetivos nacionais (atuais e permanentes) que Golbery do Couto e Silva elabora. Dentro do esquema geopolítico e seus fundamentos ideológicos, a segurança nacional aspira garantir independência da nação brasileira frente a outras potências mundiais; soberania para a autodeterminação da nação brasileira; integridade territorial, o que assegura a segurança física; progresso que emanciparia a nação do atraso socioeconômico; preservação de valores morais e espirituais que garantiria, no contexto de guerra fria, a convicção capitalista da livre iniciativa e da propriedade enquanto direito constituinte do Estado nacional (MEDEIROS, 2012).

Projeto civilizador e conquista - categorias recorrentes no planejamento do futuro para a Amazônia brasileira. O projeto civilizador é o próprio espírito de tudo o que comentamos anteriormente, ou seja, é o pano de fundo que motiva e justifica empreendimentos governamentais e particulares para inscrever no território amazônico obras de infraestrutura e de exploração de recursos naturais. A lógica é a do projetismo (PARESCHI, 2002), i.e., um pacote de técnicas e procedimentos supostamente adequados para lidar com o atraso em qualquer lugar do território de modo padronizado. A conquista segue definição semelhante.

Ameaça internacional/cobiça internacional - a formação do território amazônico e as constantes disputas nas fronteiras, principalmente com Inglaterra, Holanda e França podem ser relidas na perspectiva da ameaça e cobiça internacionais. Arthur Cezar Ferreira (1960; 1965) combina fatos históricos com uma interpretação de que há interesses das potências econômicas e militares mundiais em controlar as riquezas naturais (minerais, madeireiras, biológicas, hidrográficas) da Amazônia. Autores de livros mais recentes, por exemplo, Máfia Verde: Ambientalismo Novo Colonialismo (Geraldo Lino, Lorenzo Carrasco; Nilder Costa e Silvia Palacios; 2005) e Estratégias Militares Dominantes (General Carlos de Meira Mattos, 1980) acreditam que as ameaças e as cobiças estão em andamento por meio da dominação ideológica ambien- talista. Para eles, os objetivos de preservação ambiental, demarcações continuadas de terras indígenas e unidades de reservas em áreas de fronteiras estão a serviço de interesses de Estados nacionais estrangeiros. Julgam haver uma articulação deliberada de serviços de inteligências, grupos de interesses, lobbies e Estados nacionais para travar o desenvolvimento brasileiro em prol de um enfraquecimento da capacidade brasileira de realizar seus potenciais. A Amazônia é apresentada como uma reserva para garantir futuras incursões e deveria ser mantida como estar (MEDEIROS, 2012).

Esse processo de institucionalização de significados que se instalam em diferentes categorias e instruem práticas territoriais é o que interessa delimitar. É o processo, em última instância, de institucionalização de espaços amazônicos, que transforma realidades socionaturais em códigos e práticas políticas e administrativas. É nomeação que está a serviço de administrar recursos dentro de uma lógica de governo da natureza para administrar as tensões, hierarquias e prioridades do poder instituído. Isso é o que dá sentido à taxonomia sobre o espaço amazônico. Argumento que as dimensões espaciais, valorativas e de governança acima delimitadas compõem o próprio significado da categoria internacionalização informando suas práticas.

Euclides da Cunha em Um Paraíso Perdido (1904), com a liberdade própria dos romancistas, profetizou que a Amazônia "mais cedo ou mais tarde, [...] há de concentrar a civilização do globo" ([1904] 1999, p. 219220). Parece que a profecia se realiza na medida em que as atenções de uma geopolítica ambiental se voltam para a natureza amazônica e na medida em que a região assume, cada vez mais, proeminência nas questões referentes à água, produção de alimentos, recursos minerais, petróleo e bioprospecção. É nesse processo de ressignificação constante que a territorialidade Amazônia é pensada e se constrói a natureza amazônica.

\section{Referências}

ALBERT, Bruce. "Indian Lands, Environmental Policy and Military Geopolitics in the Development of the Brazilian Amazon: The Case of the Yanomami”. Development and Change (SAGE, London, Newbury Park and New Delhi), v. 23, p. 35-70, jan/jun. 1992.

ARON, Raymond. Paz e Guerra entre as Nações. São Paulo: Imprensa Oficial do Estado de São Paulo, 2002. 
ARRUDA, Gilmar. Cidades e sertões: entre história e a memória. Bauru: Edusc, 2000.

BACKEUSER, Everaldo. A estrutura política do Brasil: notas prévias. Rio de Janeiro: Mendonça Machado \& Cia, 1926.

BACKEUSER, Everaldo. A nova concepção de geografia. Revista da Sociedade de Geografia do Rio de Janeiro, Rio de Janeiro, Tomo 21, p. 75-89, jan/jun. 1927.

BACKEUSER, Everaldo. Problemas do Brasil: estrutura geopolítica. O espaço. Rio de Janeiro: Omnia, 1933.

BECKER, Berta; MIRANDA, Mariana; MACHADO, Lia Osório. Fronteira Amazônica: questões sobre a gestão do território. Brasília: UnB, 1990.

BECKER, Bertha. "Geopolítica da Amazônia”. Estudos Avançados, São Paulo, v. 19, n. 53, 71-83, jan/jun. 2005.

BECKER, Bertha. Amazônia: geopolítica na virada do III milênio. Rio de Janeiro: Garamond, 2007.

BECKER, Bertha. Geopolitica da Amazônia: a nova fronteira de recursos. Rio de Janeiro: Zahar, 1982.

CABREIRA, Márcia Maria. Vargas e o rearranjo espacial do Brasil: a Amazônia Brasileira - Um estudo de caso. 1996. Dissertação (Mestrado) - Programa de Pós-Graduação em Geografia Humana da USP, Universidade de São Paulo, São Paulo, 1996.

CASTRO, Iná Elias de. Geografia e política: território, escalas de ação e instituições. Rio de Janeiro: Bertrand Brasil, 2004.

CASTRO, Therezinha de. Geopolítica: princípios, meios e fins. Rio de Janeiro: Biblioteca do Exército, 1999.

CLAUSEWITZ, Carl Von. Da guerra. Lisboa: Perspectiva \& Realidade, 1976.

COSTA, Wanderley Messias da. Geografia política e geopolítica. São Paulo: Hucitec/Edusp, 1992.

CUNHA Euclides da. Euclides da Cunha: obras completas (em dois volumes). Biblioteca Luso-Brasileira. Rio de Janeiro: Nova Aguilar, 1995. (Série Brasileira)

CUNHA Euclides da. Geopolítica e poder no Brasil. Campinas: Papirus, 1995.

CUNHA Euclides da. Obras completas. Ensaios: À Margem da História/Amazônia. Rio de Janeiro: José Olympio, 1995.

CUNHA Euclides da. Um paraíso perdido. Reunião de Ensaios Amazônicos. Coleção Brasil 500 anos. Brasília: Senado Federal, [de 1904 a 1908] 1999/2000.
ESCOLA SUPERIOR DE GUERRA. Estrutura do poder nacional para o ano 2001. 1990-2000: a década vital por um Brasil moderno e democrático. Rio de Janeiro: Escola Superior de Guerra, 1989.

LIGUORI, Guido. Roteiros para Gramsci. Rio de Janeiro: UFRJ, 2007.

LINO, Geraldo et al. Máfia verde 2: ambientalismo, novo colonialismo. Rio de Janeiro: Capax Dei, 2005.

MATTOS, General Meira. Uma Geopolítica Pan-Amazônica. Coleção General Benício. Rio de Janeiro: Biblioteca do Exército, 1980.

MEDEIROS, Rodrigo Augusto Lima de. Decodificando a Internacionalização da Amazônia em narrativas e práticas institucionais: governos da natureza no Brasil e nos EUA. 2012. Tese (Doutorado) - CEPPAC/ICS/Universidade de Brasília, Brasília, 2012.

MIYAMOTO, Shiguenoli. O pensamento geopolítico brasileiro (1920-1980). 1981. Dissertação (Mestrado) - Faculdade de Filosofia, Letras e Ciências Humanas da USP, Universaidade de São Paulo, São Paulo, 1981.

PARESCHI, Ana Carolina C. Desenvolvimento sustentável e pequenos projetos: entre o projetismo e as dinâmicas sociais. 2002. Tese (Doutorado) - Departamento de Antropologia, Universidade de Brasília, Brasília, 2002.

RAFFESTIN, Claude. Écogénese territoriale et territorialité. In: AURIAC, Franck; BRUNET, Roger. (Coord.). Espaces, jeux et enjeux. Paris: Fayard, 1986. p. 173-185.

RAFFESTIN, Claude. Por uma geografia do poder. Tradução de Maria Cecília França. São Paulo: Ática, 1993.

RATZEL, F. Géographie politique. Paris: Econômica, 1988.

REIS, Arthur Cezar Ferreira. A Amazônia e a cobiça internacional. Rio de Janeiro: Companhia Editora Americana, 1973.

REIS, Arthur Cezar Ferreira. A Amazônia que os portugueses revelaram. [Brasília]: Ministério da Educação e Cultura: Serviço de Documentação, 1965. (Coleção Vida Brasileira).

REIS, Arthur Cezar Ferreira. Limites e demarcações na Amazônia Brasileira: a fronteira colonial com a Guiana Francesa. Belém: Secretaria do Estado da Cultura, 1993.

REIS, Arthur Cezar Ferreira. Limites e demarcações na Amazônia Brasileira: a fronteira com as colônias espanholas. Belém: Secretaria do Estado da Cultura, 1993.

REIS, Arthur Cezar Ferreira. O impacto amazônico na civilização brasileira. Rio de Janeiro, INL, 1972. 
RIBEIRO, Gustavo Lins. Ambientalismo e Desenvolvimento Sustentado. Nova Utopia/Ideologia do Desenvolvimento. Revista de Antropologia, [Florianópolis], n. 34, p. 59-101, semestral, 1991a.

RIBEIRO, Gustavo Lins. O Capital da Esperança: a experiência dos trabalhadores na construção de Brasília. Brasília: UnB, 2008.

SANTOS, Milton. Por uma geografia nova: da crítica da geografia a uma geografia crítica. São Paulo: Universidade de São Paulo, 2002.

SILVA, Golbery do Couto. Conjuntura Política Nacional: o poder executivo e geopolítica do Brasil. 7. ed. Brasília: UnB, 1981a. (Coleção temas brasileiros).

SILVA, Golbery do Couto. Planejamento estratégico. 2. ed. Brasília: UnB, 1981b.
SILVA, Golbery do Couto. Geopolítica do Brasil. 2. ed. Rio de Janeiro: Livraria J. Olympio, 1967. (Coleção Documentos Brasileiros, 126).

SODRÉ, Nelson Werneck. História militar do Brasil. 3. ed. Rio de Janeiro: Civilização Brasileira, 1979.

SPRANDEL, Márcia Anita. Breve genealogia sobre os estudos e fronteiras e limites no Brasil. In: OLIVEIRA, Roberto Cardoso de; BAINES, Stephen G. (Org.) Nacionalidade e etnicidade em fronteiras. Brasília: UnB, 2005. p. 153-203.

TRAVASSOS, Mario. Projeção Continental do Brasil. São Paulo: Companhia Editora Nacional, 1938. Biblioteca Pedagogica Brasileira. (Série 5a Brasiliana, v. 50). 